Gut, 1972, 13, 614-620

\title{
Impaired lymphocyte reactivity against tumour cells in patients with Crohn's disease
}

\author{
B. P. MACLAURIN, ${ }^{1}$ W. T. COOKE, AND N. R. LING
}

From the Department of Experimental Pathology, University of Birmingham, and the Birmingham General Hospital

SUMMARY Evidence is presented which indicates a possible reduction in recognition capacity for tumour cell antigens (EB, Burkitt lymphoma cell line) by lymphocytes from some patients with longstanding but inactive Crohn's disease. Three out of seven patients tested also showed diminished or absent lymphocytotoxicity when their cells were grown in mixed culture with chromium-labelled lymphoma cells and absent response has never been observed in a large series of controls similarly tested. In both test systems impaired reactivity appeared to be partly caused by a factor present in Crohn's disease serum.

Increased tumour incidence in Crohn's disease may in part be attributable to defective immune surveillance and the histology of Crohn's disease could reflect an imbalance between the proliferative and the cytotoxic responses of lymphocytes to various antigens in the bowel lumen in this disease.

Some patients with regional enteritis show evidence of impaired cell-mediated immunity, as shown by partial or complete failure to react to DNCB skin sensitization and impaired skin reactivity to tuberculin and other commonly encountered antigens (Verrier Jones, Housley, Ashurst, and Hawkins, 1969). Preliminary reports have also suggested that the lymphocytes of some patients with Crohn's disease show impaired responsiveness on stimulation with phytohaemagglutinin (Walker and Greaves, 1969). The granulomatous character of the typical bowel lesions shows a resemblance to sarcoidosis and some patients with Crohn's disease have been shown to react in weak but characteristic manner to a Kveim antigen by skin testing (Mitchell and Rees, 1970) and by inhibition of macrophage migration in the presence of this antigen (Willoughby and Mitchell, 1971).

Wyatt (1969), in a study of reported cases of adenocarcinoma of the small bowel complicating Crohn's disease, found 17 examples and noted that the mean age of occurrence was almost 20 years earlier than would be expected from the available world figures. A similar conclusion was reached by Mottet (1971) and by Papp and Pollard (1971),

Requests for reprints should be addressed to B.P.M., Department of Medicine, University of Otago Medical School, Dunedin, New Zealand.

Received for publication 30 May 1972. who recently reviewed this association, and the latter authors also noted that there was a preponderance of tumour involvement in the ileum with Crohn's disease as compared with a more frequent distribution in the duodenum and jejunum in the absence of Crohn's disease. Statistical support for an increased incidence of cancer of the small intestine and carcinoma of the pancreas in patients with Crohn's disease has been claimed (Fielding, Prior, Whitehouse, and Cooke (1972). In addition, three cases of reticulum cell sarcoma of bowel complicating Crohn's disease have been reported(Hughes, 1955; Wyburn-Mason, 1968) and patient W.S. in the present study - and a patient with Hodgkin's disease arising in a segment of jejunum involved by longstanding Crohn's disease is at present under my care. This case was reported at a recent meeting of the Royal Australasian College of Physicians (Scott and Maclaurin, 1971) but histological confirmation of the onset of Hodgkin change was not obtained until after this meeting.

It seemed possible that this apparent tumour susceptibility might relate to diminished lymphocyte competence in immune surveillance as postulated by Burnet (1969). To test this possibility, lymphocytes from Crohn's disease patients were grown in mixed culture with irradiated tumour cells from a Burkitt lymphoma cell line and their proliferative and cytotoxic capacity against the tumour 
cells was measured. Normal lymphocytes show intense proliferation and cytotoxic capacity in this test system (Hardy and Ling, 1969; Hardy, Knight, and Ling, 1970a; Hardy, Ling, Wallin, and Aviet, 1970b). The findings indicate a gross defect in cytotoxic capacity and a mild defect in proliferative capacity of the lymphocytes from some patients with Crohn's disease as compared with normal controls.

\section{Methods}

Lymphocyte-rich, washed cell suspensions were separately prepared from peripheral blood of patients and control normal subjects, placed in Eagle's culture medium supplemented with $10 \%$ serum, and dispersed in $1 \mathrm{ml}$ aliquots to multiple culture tubes, each containing $1 \times 10^{8}$ viable lymphocytes. For mixed cultures, $2 \times 10^{5}$ viable but irradiated lymphoma cells from a Burkitt cell line $\left(E_{2}\right)$ were added to triplicate test cultures, with triplicate untreated and phytohaemagglutinin(PHA) treated cultures as controls. After incubation for three days (PHA cultures) or five days the lymphocyte proliferative response was assessed by tritiated thymidine $\left({ }^{3} \mathrm{HTdr}\right)$ incorporation into DNA.

The cytotoxic capacity of lymphocytes from patients and controls was assessed by measurement of ${ }^{51} \mathrm{Cr}$ release over a six-hour period from prelabelled lymphoma cells. A full description of the methods used has been given in an earlier paper (Maclaurin, Cooke, and Ling, 1971).

\section{Patients Studied}

All were under the care of W.T.C. and on longterm follow-up and supervision. The case details are shown in brief in Table I. In all cases, the disease involved both small and largel bowel, and the diagnosis was firmly established on clinical, radiological, and laboratory criteria. In all but one case, histological proof was also available. Patients were classified as having active or inactive disease, with particular emphasis upon weight, Hb, ESR, and seromucoid estimation, recent surgery, and general well being. Control subjects were all fit medical students or staff and were selected and studied in a manner identical with that described in the coeliac disease paper (Maclaurin et al, 1971).

\section{Results}

1 RESPONSE TO EB LYMPHOMA CELLS

The findings are shown in Table $I$ and compared with the results for normal lymphocytes in Figure 1. The pattern of response corresponds to some degree with the state of activity of the patient's disease, with low responders mostly having inactive disease. An analysis of variance for the whole series of results compared with the results for normal lymphocytes shows no significant difference $(P>0 \cdot 2)$.

Culture of washed Crohn's disease lymphocytes in medium supplemented with fresh normal serum instead of Crohn's disease serum produced a considerable rise in ${ }^{3} \mathrm{HTdr}$ incorporation in seven out of

\begin{tabular}{|c|c|c|c|c|c|c|c|c|c|c|c|}
\hline & \multirow[t]{2}{*}{ Patient } & \multirow[t]{2}{*}{ Age } & \multirow[t]{2}{*}{$\operatorname{Sex}$} & \multirow[t]{2}{*}{ Nutrition } & \multirow{2}{*}{$\begin{array}{l}\text { Duration of } \\
\text { Symptoms } \\
\text { in Years }\end{array}$} & \multicolumn{4}{|c|}{${ }^{2} H T d r$ Incorporation Increment on Culture-DPM } & \multicolumn{2}{|c|}{${ }^{3} H T d r$ Incorporation-DPM } \\
\hline & & & & & & $\begin{array}{l}\text { With EB, } \\
\text { Cells in } \\
\text { Own Serum }\end{array}$ & $\begin{array}{l}\text { With EB } \\
\text { Cells in } \\
\text { Normal } \\
\text { Serum }\end{array}$ & $\begin{array}{l}\text { With } P H A \\
\text { in Own } \\
\text { Ser:um }\end{array}$ & $\begin{array}{l}\text { With PHA } \\
\text { in Normal } \\
\text { Serum }\end{array}$ & $\begin{array}{l}\text { Unstimulated } \\
\text { in Own } \\
\text { Serum }\end{array}$ & $\begin{array}{l}\text { Unstimulated } \\
\text { in Normal } \\
\text { Serum }\end{array}$ \\
\hline $\mathbf{A}$ & $\begin{array}{l}\text { Patients n } \\
\text { E.E. } \\
\text { J.T. } \\
\text { D.U. } \\
\text { T.D. }{ }^{1} \\
\text { R.R. } \\
\text { R.N. } \\
\text { C.P. }\end{array}$ & $\begin{array}{l}\text { ith acti } \\
45 \\
36 \\
38 \\
40 \\
26 \\
40 \\
25\end{array}$ & $\begin{array}{l}\text { ve disease } \\
\mathbf{F} \\
\mathbf{F} \\
\mathbf{F} \\
\mathbf{M} \\
\mathbf{M} \\
\mathbf{M} \\
\mathbf{M}\end{array}$ & $\begin{array}{l}\text { Impaired } \\
\text { Normal } \\
\text { Impaired } \\
\text { Normal } \\
\text { Impaired } \\
\text { Impaired } \\
\text { Impaired }\end{array}$ & $\begin{array}{r}9 \\
7 \\
13 \\
17 \\
16 \\
13 \\
2\end{array}$ & $\begin{array}{r}56211 \\
31116 \\
52863 \\
7795 \\
52042 \\
67017 \\
7468\end{array}$ & $\begin{array}{l}- \\
56722 \\
11641 \\
23879 \\
66157 \\
50897 \\
11554\end{array}$ & $\begin{array}{l}62613 \\
84238 \\
25612 \\
32314 \\
30414 \\
33066 \\
11650\end{array}$ & $\begin{array}{l}- \\
\overline{-} \\
12071 \\
48415 \\
3533 \\
7059\end{array}$ & $\begin{array}{r}300 \\
1045 \\
1040 \\
1236 \\
790 \\
2190 \\
817\end{array}$ & $\begin{array}{r}- \\
2574 \\
135 \\
2062 \\
921 \\
2000 \\
1056\end{array}$ \\
\hline \multicolumn{2}{|c|}{ Group mean } & 36 & & & 11 & 39216 & 36808 & 39986 & 17769 & 1059 & 1458 \\
\hline $\mathbf{B}$ & $\begin{array}{l}\text { Patients n } \\
\text { W.S. } \\
\text { P.M. } \\
\text { D.G. } \\
\text { J.R. } \\
\text { J.H. } \\
\text { A.J. }\end{array}$ & $\begin{array}{l}\text { ith inac } \\
60 \\
59 \\
32 \\
24 \\
48 \\
15\end{array}$ & $\begin{array}{l}\text { tive diseo } \\
\text { M } \\
\mathbf{M} \\
\mathbf{F} \\
\mathbf{F} \\
\mathbf{F} \\
\mathbf{M}\end{array}$ & $\begin{array}{l}\text { Normal } \\
\text { Normal } \\
\text { Normal } \\
\text { Impaired } \\
\text { Normal } \\
\text { Normal }\end{array}$ & $\begin{array}{r}13 \\
25 \\
23 \\
15 \\
22 \\
1\end{array}$ & $\begin{array}{r}53426 \\
29626 \\
4174 \\
8107 \\
1114 \\
34919\end{array}$ & $\begin{array}{l}43126 \\
46749 \\
7013 \\
23233 \\
-\end{array}$ & $\begin{array}{l}11240 \\
31093 \\
15475 \\
11296 \\
19572 \\
11628\end{array}$ & $\begin{array}{l}4492 \\
36090 \\
11543 \\
2393 \\
-\end{array}$ & $\begin{array}{r}410 \\
257 \\
712 \\
1732 \\
1221 \\
3292\end{array}$ & $\begin{array}{l}452 \\
3506 \\
1107 \\
1584 \\
-\end{array}$ \\
\hline & $\begin{array}{l}\text { oup mean } \\
\text { rall mean }\end{array}$ & $\begin{array}{l}40 \\
37\end{array}$ & & & $\begin{array}{l}16 \\
14\end{array}$ & $\begin{array}{l}21894 \\
31221\end{array}$ & $\begin{array}{l}30030 \\
34097\end{array}$ & $\begin{array}{l}16717 \\
29247\end{array}$ & $\begin{array}{l}13629 \\
15699\end{array}$ & $\begin{array}{l}1270 \\
1157\end{array}$ & $\begin{array}{l}1662 \\
1539\end{array}$ \\
\hline
\end{tabular}

Table Crohn's disease patients studied

${ }^{2} \mathrm{On} \mathrm{ACTH,} 10 \mathrm{u} / \mathrm{day} \quad{ }^{2} \mathrm{On} \mathrm{ACTH}, 20 \mathrm{u} /$ day (one month only) ${ }^{3}$ Reticulum cell sarcoma of caecum resected $10 \mathrm{yr}$ ago. 


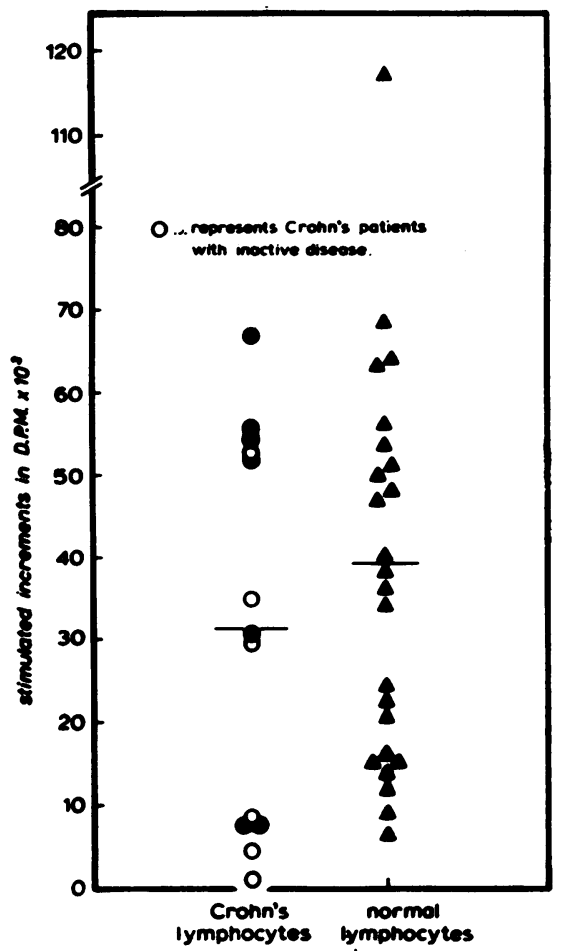

Fig. 1 Comparison of proliferative response to lymphoma cells $\left(E B_{2}\right)$ by Crohn's disease lymphocytes and by normal lymphocytes in medium supplemented with autologous serum (measured by ${ }^{3} \mathrm{HTdr}$ incorporation into DNA).

10 patients tested, with a mean $50 \%$ increase (Fig. 2). Culture of washed normal lymphocytes in medium supplemented with Crohn's disease serum produced the reverse effect in six out of nine tests.

\section{$2{ }^{3} \mathrm{HTdr}$ INCORPORATION BY UNSTIMULATED LYMPHOCYTES IN AUTOLOGOUS OR NORMAL SERUM}

These results are listed in Table I and compared with values for normal lymphocytes in Figure 3. Seven out of 10 patients tested showed improved thymidine incorporation in normal serum and responses of six out of nine normal subjects tested were diminished in Crohn's disease serum. An analysis of variance shows that for the numbers of cases studied there is a possible but by no means definite depression of incorporation by Crohn's disease lymphocytes (grown in Crohn's disease serum) $(\mathrm{P}<0.2>0 \cdot 1)$.

\section{RESPONSE TO PHA}

These results are listed in Table I and compared with the response of normal lymphocytes in Figure

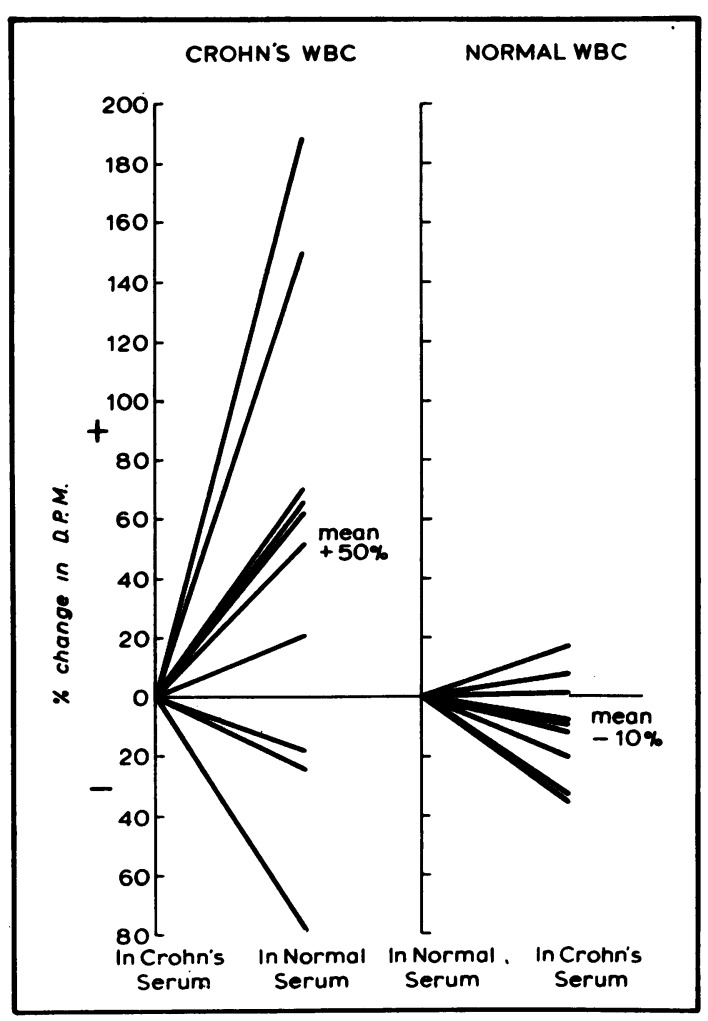

Fig. 2 Comparison of proliferative response to $E B_{2}$ cells by lymphocytes grown in medium supplemented with normal serum or with Crohn's disease serum.

4. Again. lymphocytes of patients with inactive disease tended to show diminished incorporation of ${ }^{3}$ HTdr. Comparison of Crohn's lymphocyte responses (in Crohn's serum) versus normal lymphocyte responses showed no significant overall difference $(P>0 \cdot 2)$. Assessment of the effect of normal serum on PHA responses of Crohn's lymphocytes revealed an overall depressive effect (six out of eight subjects tested) with a mean reduction of thymidine incorporation by $30 \%$ and this reduction is possibly significant $(P>0.05<0 \cdot 1)$.

\section{CYTOTOXICITY}

These results are shown in Fig. 5 and compared with the mean responses of 11 normal subjects (quoted by Maclaurin et al, 1971). It will be noted that in two patients cytotoxicity was virtually absent and in a third it was markedly diminished and below the range for the normal subjects studied.

Parallel assessments of cytotoxicity for Crohn's lymphocytes grown in normal serum and for normal lymphocytes grown in Crohn's disease serum showed 


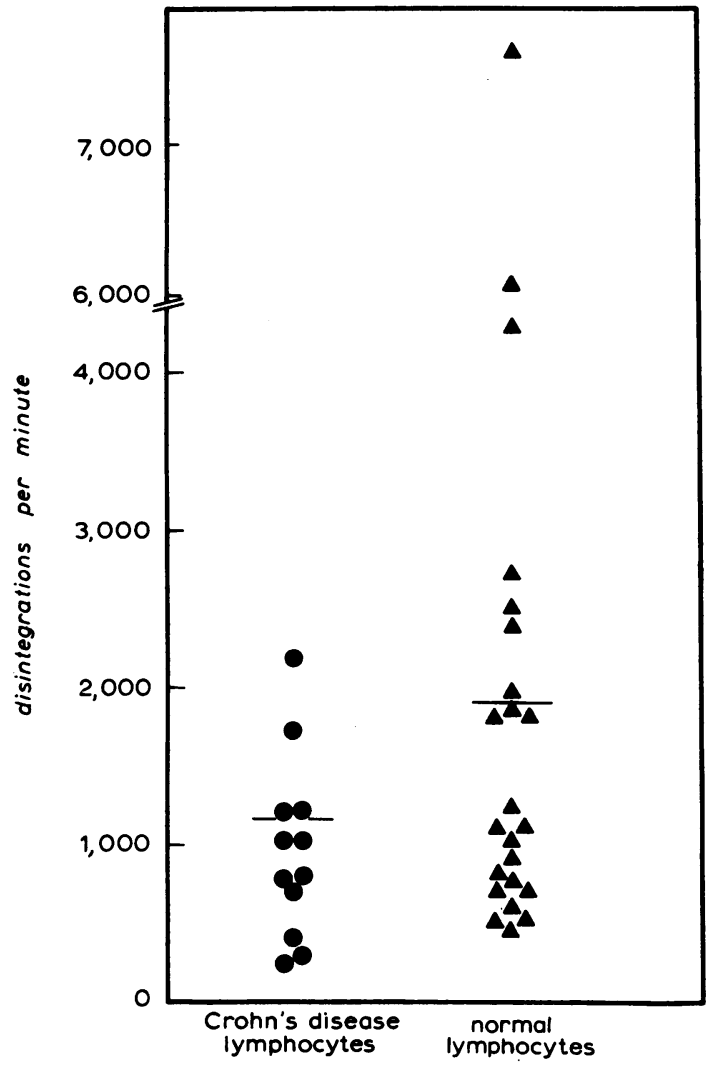

Fig. 3 Comparison of ${ }^{3} H T d r$ incorporation into DNA by unstimulated lymphocytes in autologous serum on the fifth day of culture.

remarkable differences from the results obtained on culture in autologous serum (Fig. 6). In particular, the serum of patient D.U. was found to convert normal lymphocyte cytotoxicity almost to zero and the serum from patient W.S. (lymphosarcoma resected 10 years previously) was also markedly inhibitory, suggesting the presence of a blocking antibody. Some support for this view was obtained by testing the lymphocytes of patient R.N. grown in autologous serum following prior absorption of this serum with $\mathrm{EB}_{2}$ cells overnight in the cold. The previously low cytotoxic response was more than doubled by the use of $\mathbf{E B}_{2}$-absorbed serum. However, serum from a patient convalescing from infectious mononucleosis (and presumably having a high EB virus antibody titre) produced marked enhancement of normal lymphocyte cytotoxicity in this test system. Further work is clearly required to determine the nature of the blocking factor in the serum of some Crohn's disease patients.

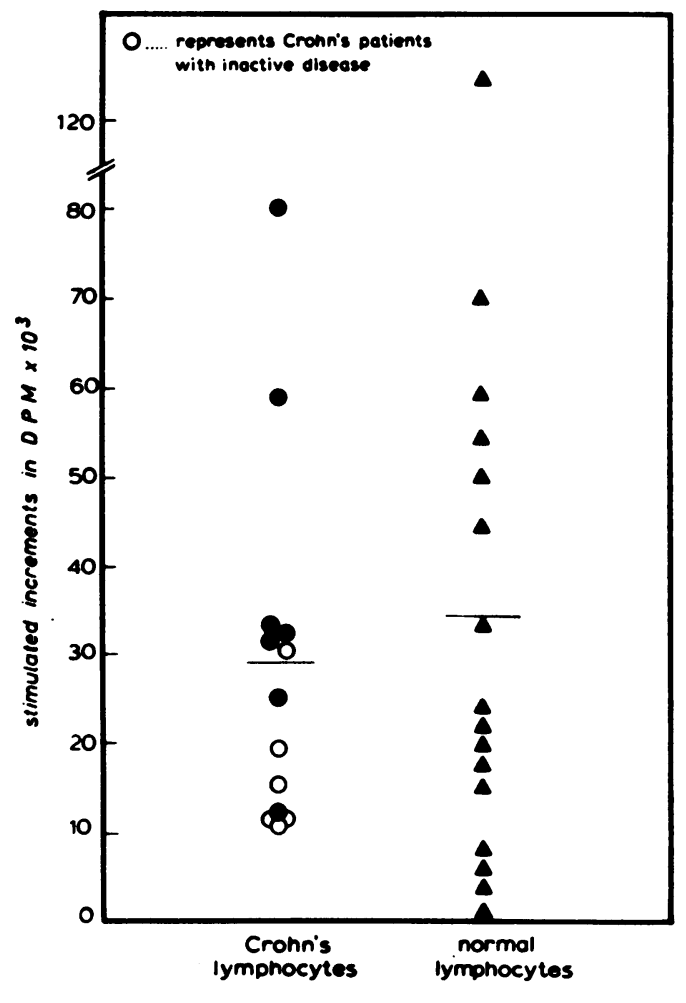

Fig. 4 Comparison of proliferative response to $\mathrm{PHA}$ by Crohn's disease lymphocytes and by normal lymphocytes grown in autologous serum $\left({ }^{3}\right.$ HTdr incorporation into $D N A)$.

\section{Discussion}

On stimulation with irradiated lymphoma cells or with phytohaemagglutinin, the proliferative response of Crohn's disease lymphocytes, especially from patients with inactive disease, was moderately diminished when compared with the response of control normal lymphocytes, but this was not statistically significant.

Parallel assessments of patients' lymphocytes stimulated in medium supplemented with homologous normal serum showed moderate improvement in EB lymphoma responsiveness. This finding, coupled with the results of serum change on ${ }^{3} \mathrm{HTdr}$ incorporation by unstimulated lymphocytes, suggests the presence of a depressive serum factor in a majority of these patients. This may be analogous to similar depressive serum factors reported in a number of chronic infectious diseases associated with long-continued massive antigenic stimulation 


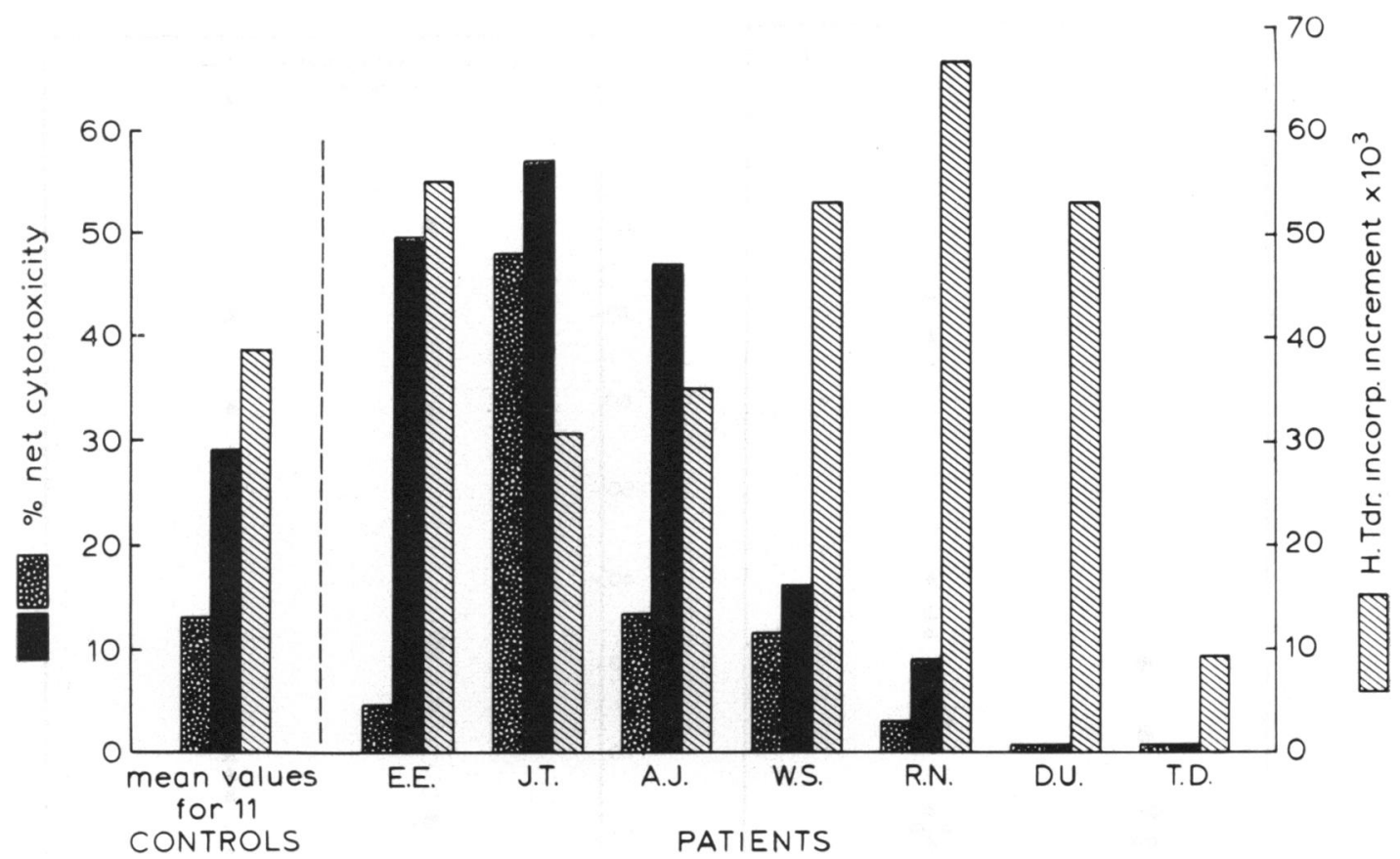

Fig. 5 Comparison of net cytotoxicity of Crohn's disease or normal lymphocytes upon ${ }^{51}$ Cr-labelled $E B_{2}$ cells over six-hour period. Net cytotoxicity $=\%{ }^{51} \mathrm{Cr}$ release in test cultures with lymphocytes-spontaneous release of label in parallel cultures identical except for the absence of lymphocytes. (Mean spontaneous release of label was $15 \%$. Range 10-20.) Stippled columns represent unstimulated lymphocyte results. Black columns indicate lymphocytes prestimulated with non-labelled, irradiated $E B_{2}$ cells. Hatched columns indicate the corresponding proliferative response to $E B_{2}$ cells of the lymphocytes under test.

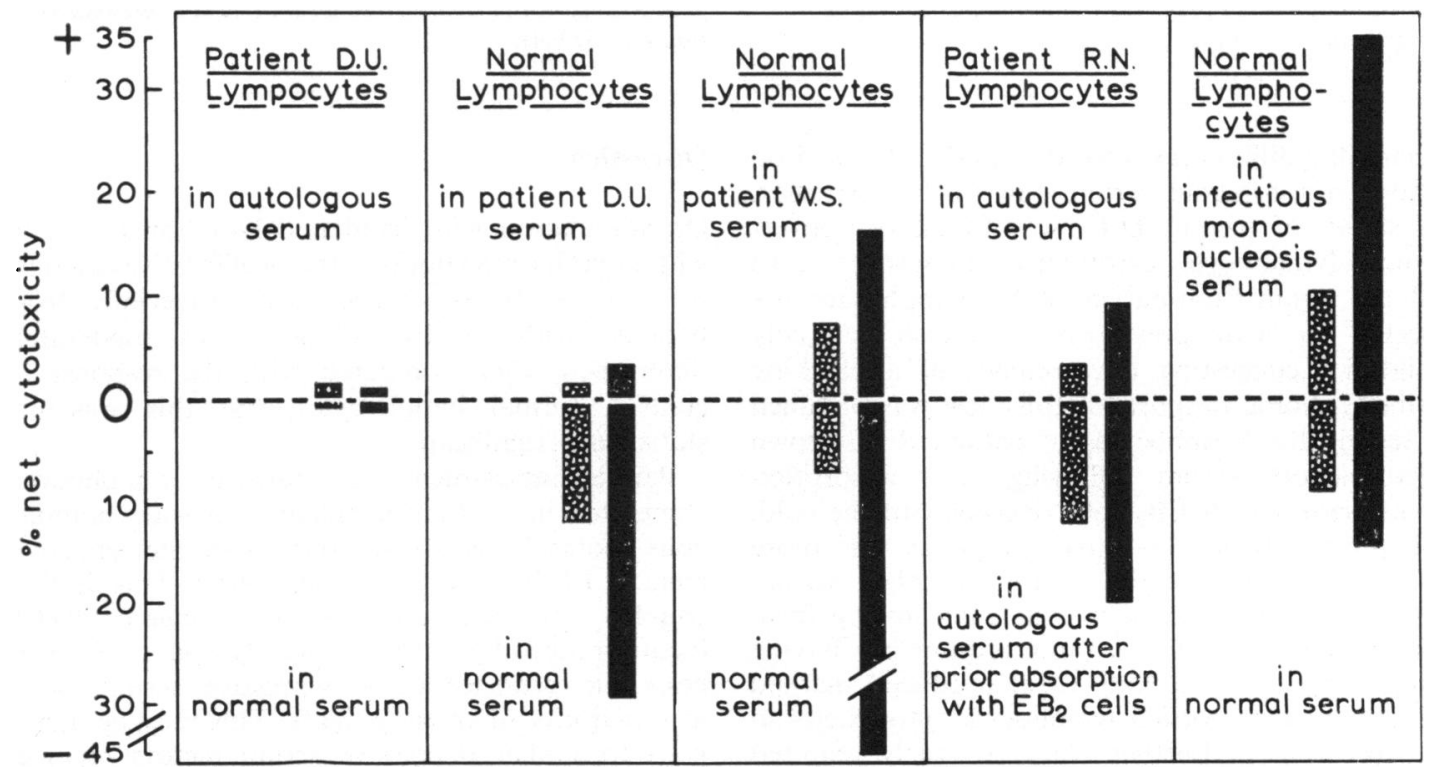

Fig. 6 Comparison of cytotoxicity of Crohn's disease or normal lymphocytes tested in various sera. Stippled and black columns indicate unstimulated and prestimulated results respectively, as in Figure 5. 
(Gatti, 1971). It also resembles the depressive factor recently reported in a series of patients with coeliac disease tested under identical conditions (Maclaurin et al, 1971). No such depressive serum factor has been found in the serum of patients with the gastric atrophy of pernicious anaemia (Maclaurin and Matthews, 1973) but in this disorder there is no breach in mucosal continuity. Only very limited studies of ulcerative colitis patients have so far been made with this test system and to date no depressive serum factor has been shown (Maclaurin, unpublished data). It is suggested that the depressive serum factor may represent an attempt at homeostasis of total lymphocyte numbers but the nature of the factor or factors has not yet been established. Alternatively, some Gram-negative bacterial products are known to have lymphocyte depressant properties and might be implicated (Floersheim, 1969). Whatever their nature, the longcontinued action of lymphocyte-depressant circulating substances might ultimately result in some permanent depression of the cellular immune response, and this appears possibly to be the case in the inactive case group with longstanding disease reported here.

The anomalous reduction in PHA stimulation of Crohn's lymphocytes by normal serum might be related to the dose used, since PHA is known to form complexes with some serum proteins (Osunkoya and Williams, 1971). However, doubling the dose used diminished the response obtained in one patient so tested. The reduction in PHA responsiveness in normal serum may explain the much lower stimulation results reported by Brown, Taub, Present, and Janowitz (1970), and the results of Walker and Greaves (1969), who used foetal calf serum for supplementing the medium. Kraft and Kirsner (1971) have emphasized, in a recent review of this subject, that interpretation of the results of studies in vitro should be cautious, since methodological changes may improve many of these apparently subnormal responses.

The composition of the case series studied, and especially the proportion of active to inactive cases, will influence the results obtained. Our findings suggest that lymphocytes from active cases mostly have well maintained proliferative responsiveness, perhaps reflecting the excessive and prolonged exposure of the lymphoid system to bacterial, viral, and food antigens in the abnormal bowel. There is recent evidence of lymphocyte hypersensitivity to faecal and colon mucosal antigens in patients with Crohn's disease compared with controls (Watson and Pinedo, 1971). A similar conclusion has been tentatively put forward by Dykes (1970) on the basis of macrophage migration inhibition studies in the presence of a faecal antigenic extract. However, Bendixen (1969), using a similar system but with a foetal colon mucosal extract as antigen, was able to demonstrate inhibition of leucocyte migration in only a small proportion of Crohn's disease patients.

The virtually complete absence of lymphocytotoxicity against chromium-labelled lymphoma cells in two of the patients studied is in marked contrast to the reasonably normal proliferative response of the same subjects' lymphocytes, stimulated simultaneously with irradiated tumour cells (Fig. 5). A third patient, W.S., showed diminished lymphocytotoxicity but maintained proliferative response. It is of interest that this subject had a resection of a reticulum cell sarcoma of the bowel (in an area involved by active Crohn's disease) 10 years before, and has been maintained in surprisingly good health ever since. These results demonstrate that there is no direct correlation between the cytotoxic and proliferative capacities of lymphocytes in this test system. In a much larger group of normal subjects studied in this laboratory (Hardy et al, 1970b, and unpublished results) complete absence of cytotoxicity has not been observed.

If it could be demonstrated that lymphocytes of patients with Crohn's disease lacked effector functional capacity in other respects, eg, production of non-specific cytotoxic factors and other lymphokines (Granger and Kolb, 1968; Dumonde, 1970), this might help to explain the massive lymphocyte accumulation in the bowel which is such a feature of this disease, ie, maintained proliferative response to bacterial or viral antigens with accumulation of only partially competent lymphocytes resulting in failure to eradicate the causative agent. Cytotoxicity after allogeneic lymphocyte stimulation as in this test system is relatively non-specific in relation to the target cell used (Hardy et al, 1970b) and impairment could well influence the response in vivo to infectious agents as well as to tumour cells. The recent report by Mitchell and Rees (1970), suggesting the presence of a transmissible infective agent in extracts of Crohn's disease tissue, capable of causing typical histological changes in immunosuppressed mice, is of great interest in this context. Their comparable findings of a transmissible agent in sarcoidosis tissue (Mitchell and Rees, 1969) and the similarities between the histology of Crohn's disease and sarcoidosis may also be relevant, since preliminary observations have shown a pattern of lymphocyte reactivity in some patients with sarcoidosis similar to that in Crohn's disease (Broom, and Maclaurin, 1973).

The impairment of cytotoxic capacity is partly serum-mediated, and might be due to antibody to 
EB virus antigens probably still carried by this lymphoma cell line.

An assessment for EB virus antibodies in the sera of 10 patients with Crohn's disease was kindly carried out by Dr G. Henle of the Children's Hospital, Philadelphia, through the courtesy of Dr G. Klein of the Karolinska Institute, Stockholm. However, the titres obtained were regarded by Dr Henle as within the expected range for a comparable age and sex range of the normal population, so that this explanation seems unlikely. Grotsky (1970) and Kane and Nye (1971) have obtained similar results for EBV antibodies in studies on Crohn's disease patients.

Impaired proliferative or cytotoxic responses could not be related to any direct cytotoxic effect or nutritional lack in the serum tested, since viabilities at the end of the five-day culture period, unstimulated, were approximately $70 \%$ and did not differ significantly from the controls. Furthermore, the sera which produced depression of cytotoxicity were found capable of sustaining high levels of proliferative response.

The remarkable absence of cytotoxicity against lymphoma cells demonstrated in vitro by lymphocytes from some patients with Crohn's disease may be an indication of a similar impairment in vivo of destructive capacity against antigenically altered tumour cell mutations of either lymphoid or mucosal cell origin. More detailed discussion of the relationship of this test system to the postulate of immune surveillance in cancer homeostasis (Burnet, 1969) is provided in the earlier paper on lymphocyte function in coeliac disease (Maclaurin et al, 1971).

B.P.M. was supported by a Nuffield Foundation travelling fellowship in medicine while on sabbatical leave from the University of Otago Medical School, New Zealand. We are grateful to Mrs Frances Levy and Miss Barbara Newey for technical assistance. The help of Dr G. Klein of the Karolinska Institute, Stockholm, and of Dr G. Henle of the Children's Hospital, Philadelphia, in the performance and interpretation of the EBV, antibody titres on Crohn's disease sera is gratefully acknowledged. Mr J. Vaughan-Smith of the Department of Experimental Pathology provided assistance in the statistical analysis of the data.

\section{References}

Bendixen, G. (1969). Cellular hypersensitivity to components of intestinal mucosa in ulcerative colitis and Crohn's disease. Gut, 10, 631-636.

Broom, B., Matthews, N., and Maclaurin, B. P. (1973). Studies on cell-mediated immune reactivity in sarcoidosis (in preparation).
Brown, S. M., Taub, R. N., Present, D. H., and Janowitz, H. D. (1970). Short-term lymphocyte cultures in regional enteritis. Lancet, 1, 1112.

Burnet, F. M. (1968). A modern basis for pathology. Lancet, 1, 1383-1387.

Dumonde, D. C. (1970). 'Lymphokines': Molecular mediators of cellular immune responses in animals and man. Proc. roy. Soc. Med., 63, 899-902.

Dykes, P. W. (1970). Delayed hypersensitivity in Crohn's disease. Proc. roy. Soc. Med., 63, 906-908.

Fielding, J. F., Prior, P., Whitehouse, J. A., and Cooke, W. T. (1972). Malignancy in Crohn's disease. Scand. J. Gastroent. 7, 3-7.

Floersheim, G. L. (1969). Suppression of cellular immunity by gram negative bacteria. Antibiot. et Chemother. (Basel), 15, 407-417.

Gatti, R. A. (1971). Serum inhibitors of lymphocyte responses. Lancet, 1, 1351-1352.

Granger, G. A., and Kolb, W. P. (1968). Lymphocyte in vitro cytotoxicity: Mechanisms of immune and non-immune small lymphocyte mediated target $\mathrm{L}$ cell destruction. J. Immunol., 101, 111-120.

Grotsky, H., Glade, P. R., Yirschaut, Y., Sachar, D., and Janowitz, H. D. (1970). Herpes-like virus and granulomatous colitis. Lancet, 2, 1256-1257.

Hardy, D. A., and Ling, N. R. (1969). Effects of some cellular antigens on lymphocytes and the nature of the mixed lymphocyte reaction. Nature (Lond.), 221, 545-548.

Hardy, D. A., Knight, S., and Ling, N. R. (1970). The interaction of normal lymphocytes and cells from lymphoid cell lines. I. The nature of the activation process. Immunology, 19, 329-342.

Hardy, D. A., Ling, N. R., Wallin, J., and Aviet, T. (1970b). Destruction of lymphoid cells by activated human lymphocytes. Nature (Lond.), 227, 723-725.

Hughes, R. K. (1955). Reticulum cell sarcoma: a case possibly originating in regional enteritis. Amer. Surg., 21, 770-773.

Jones, J. V., Housley, J., Ashurst, P. M., and Hawkins, C. F. (1969). Development of delayed hypersensitivity to dinitrochlorobenzene in patients with Crohn's disease. Gut, 10, 52-56.

Kane, S. P., and Nye, F. J. (1971). E.B.-virus antibody in Crohn's disease. Lancet, 1, 233.

Kraft, S. C., and Kirsner, J. B. (1971). Immunological apparatus of the gut and inflammatory bowel disease. Gastroenterology, $60,922-951$.

Maclaurin, B. P., Cooke, W. T., and Ling, N. R. (1971). Impaired lymphocyte reactivity against tumour cells in patients with coeliac disease. Gut, 12, 794-800.

Maclaurin, B. P., and Matthews, N. (1973). Cell-mediated immunity in patients with pernicious anaemia (in preparation).

Mitchell, D. N., and Rees, R. J. W. (1969). A transmissible agent from sarcoid tissue. Lancet, 2, 81-84.

Mitchell, D. N., and Rees, R. J. W. (1970). Agent transmissible from Crohn's disease tissue. Lancet, 5, 168-171.

Mottet, N. K. (1971). Histopathologic Spectrum of Regional Enteritis and Ulcerative Colitis, p. 218. Saunders, London.

Osunkoya, B. O., and Williams, A. I. O. (1971). Precipitation of serum proteins by phytohaemagglutinin. Clin. exp. Immunol., 8, 205-212.

Papp, J. P., and Pollard, H. M. (1971). Adenocarcinoma occurring in Crohn's disease of the small intestine. Amer. J. Gastroent., 56, 149-156.

Scott, A. J., and Maclaurin, B. P. (1971). A patient with Crohn's disease involving the stomach, duodenum and jejunum (Abstr.) Aust., N.Z. J. Med., 1, 336-337.

Walker, J. G., and Greaves, M. F. (1969). Delayed hypersensitivity and lymphocyte transformation in Crohn's disease and proctocolitis. Gut, 10, 414.

Watson, D. W., and Pinedo, G. (1971). Lymphocyte stimulation by colonic and fecal antigens in patients with ulcerative colitis and Crohn's disease. (Abstr.) Clin. Res., 19, 177.

Willoughby, J. M. T., and Mitchell, D. N. (1971). In vitro inhibition of leucocyte migration in Crohn's disease by a sarcoid spleen suspension. Brit. med. J., 3, 155-157.

Wyatt, A. P. (1969). Regional enteritis leading to carcinoma of the small bowel. Gut, 10, 924-927.

Wyburn-Mason, R. (1968). Crohn's disease and carcinoma of colon (Letter). Brit. med. J., 2, 697. 